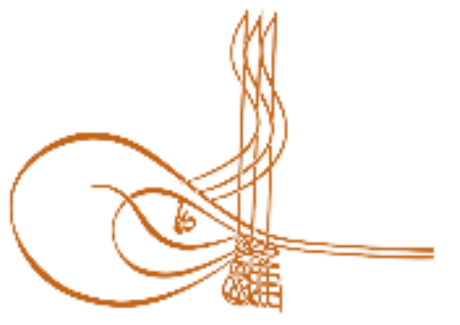

www.turkishstudies.net/turkishstudies
Turkish Studies

eISSN: $1308-2140$

Research Article / Araştırma Makalesi

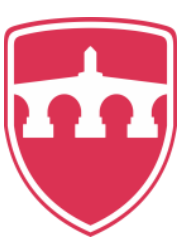

INTERNATIONAL

BALKAN

UNIVERSITY

Sponsored by IBU

\title{
Özdilek Mecmuasına Göre Trabzon ve Havalisinde Eğitimin Gündemi
}

According to Özdilek Journal, the Agenda of Education in the Region of Trabzon

Alev Duran*

\begin{abstract}
: Özdilek journal which is a monthly published, professional, literate, scientific journal started to be published on July 10, 1923 and publisher teacher of it is Cemal Güntekin. Since the publisher worked in Sivas, it started to be published in Sivas, then in Erzurum, lastly continued to be published for a long time in Trabzon. At first, it started to be published as a province school media and it continued publishing life like first day till closed. Because the main aim of journal was education, the school have gained importance. In almost every issue, the contents related to cultural life of people and youth have been published. It not only gave an importance to Turkish quarry and also inluded in literate and scientific articles and played a quite significant role in the transmission of republic ideas. Also, during this period of intense revolutions, it carried out activities to help the youth to internalize such revolutions and to support them. The agenda of education and training was evaluated through subjects that were decided by officials of the conference and conferences given in a term at the extent journal. The fact that the regulations issued by the ministry of education have also been included in it is a proof that has showed the priority of it is education. In this study, the education and teaching news, ideas and articles in the region of Trabzon of Özdilek which is a literate and scientific journal started to be published in a difficult period have been researched. The aim is to englighten that period by researching education news, issues and subjects through missions of the new education and ministry.
\end{abstract}

Structured Abstract: Özdilek journal which is a monthly published, professional, literate, scientific journal started to be published on July 10, 1923 and publisher teacher of it is Cemal Güntekin. Since the publisher worked in Sivas, it started to be published in Sivas, then in Erzurum, lastly continued to be published for a long time in Trabzon. At first, it started to be published as a province school media and it continued publishing life like first day till closed.

Because the main aim of journal was education, the school have gained importance. In almost every issue, the contents related to cultural life of people and youth have been published. It not only gave an importance to Turkish quarry and also inluded in literate and scientific articles and played a quite significant role in the transmission of republic ideas. Also, during this period of intense revolutions, it carried out activities to help the youth to internalize such revolutions and to support them. The agenda of education and training was evaluated through subjects that were decided by officials of the conference and conferences given in a term at

\footnotetext{
* Dr. Öğr. Üyesi, İstanbul Aydın Üniversitesi, Fen-Edebiyat Fakültesi, Tarih Bölümü Asst. Prof. Dr., Ístanbul Aydin University, Faculty of Science and Letters, Department of History ORCID 0000-0000-0003-0995-8090

alevduran@aydin.edu.tr

Cite as/ Atıf: Duran A. (2020). Özdilek Mecmuasına göre Trabzon ve havalisinde eğitimin gündemi, Turkish Studies, 15(1), 133-146 https://dx.doi.org/10.29228/TurkishStudies.39805

Received/Geliş: 18 November/Kasım 2019

Accepted/Kabul: 25 February/Şubat 2020

Checked by plagiarism software

Copyright $(\mathrm{C}$ MDE, Turkey 
the extent journal. The fact that the regulations issued by the ministry of education have also been included in it is a proof that has showed the priority of it is education.

In this study, the education and teaching news, ideas and articles in the region of Trabzon of Özdilek which is a literate and scientific journal started to be published in a difficult period have been researched. The aim is to englighten that period by researching education news, issues and subjects through missions of the new education and ministry.

The region of Trabzon has a subtantial content as publishing life. At the stage of realizing revolutions and founding republic, media life of the city has gained a new color by moving of Özdilek Journal to Trabzon. Also, it has addressed to the youth and continued its activities to help them to internalize republic revolutions and to support these.

"Özdilek has given great importance to the issues of collective teaching, social studies, alphabet by word method, education systems, and disciplinary tools that has constituted the most fundamental and spirited subjects of our education lives and and revolutions. It has considered as a perspective mission showing the values of these issues in the application stage, the shapes and the outlines of the plan and curriculum that will be made in accordance with local rules..." This statement has clearly indicated the aim of journal as well as it has emphasized the effect and importance of education and teaching management.

It has been stated that the writers of Özdilek journal need to write their road maps, ideas that include in issues are related to education, to put in process the results of pedagogic application experiences. "The most important issue that we need to take attention is to make the children a valuble element that will be able to easily live with the requirements and necessities of today, and especially tomorrow and that will be able to give life to the life of a mass that will be able to successfully walk on the path of maturation, who we took them to raise while returning to the Turkish community and life".

The publishing manager of Özdilek journal Cemal Gültekin has indicated the aims of journal by his own words "taking powder and strenght from the divine principles of our great faith is to raise the Turkish child as an excited citizen, a good producer, a passionate republican and creative characters who will be able to struggle against all the difficulties and the troubles of life and to win this war. There are traces in journal of his educator personality as well as an advocate of Atatürk revolutions".

Özdilek journal has undertaken to do education works and to raise educator as an aim to set off, has played a role in supporting new ideas during the period of intense revolutions. In this study, articles are related to education, evaluations on education and teaching problems will be researched and in this way, a framework for educational perspective of the period will be established. The region of Trabzon has a subtantial range of publishing in the period moved from the Ottoman Empire to the Rebuplic. Its publication life was much more enriched by the help of continuing its activities İstiklal Printing House in Trabzon at the phase of the realization of revolutions and the establishment of Republic. It played a suitable role in accordence with the ethics and the priciples of the publication, among the difficulties of structuring a newly organized state, intensely realized revolutions. Espeacially, in the journal addressed to young readers continued to its activities that tended to internalize innovations and to support these innovations. The mission was accepted the main role of it and it was used as a tool to constitute this mission. This idea was stated in 9-5 numbered publishment of the journal in 1339 "It accepted as a mission to show the values at the stage of application, the outlines and the shapes of the plan and curriculum programs". The importance and the effect of education and teaching management was emphasized with the statement which clearly indicated the aim of journal.

Teachers and writers stated that they needed to write their ideas that were related to education to put in process the results by taken pedagogic experiences. They published required number of articles in this direction "The most important issue that we need to take attention is to make the children a valuble element that will be able to easily live with the requirements and necessities of today, and especially tomorrow and that will be able to give life to the life of a mass that will be able to successfully walk on the path of maturation, who we took them to raise while returning to the Turkish community and life" Since it contributed the publishment life such as to support agenda of education at the region of Trabzon and revolutions as a journal, this moved it an important place.

Keywords: Journal, Media, Ministry, Trabzon, Özdilek, History of Education. 
Öz: 10 Temmuz 1923 'te yayın hayatına başlayan Özdilek mecmuası, aylık meslekî, edebî, ilmî bir dergi olup imtiyaz sahibi öğretmen Cemal Gültekin'dir. İmtiyaz sahibinin Sivas’ta görev yapması nedeniyle dergi yayın hayatına Sivas'ta başlamış, ardından Erzurum'da ve son olarak Trabzon'da yayınına uzun soluklu olarak devam etmiştir. Özdilek Mecmuası öncelikle bir vilayet mektebi yayın organı olarak neşir hayatına başlamış, kapatılana kadar da çizgisini korumuştur. Derginin temel gayesi öğretim işleri olduğu için okula önem verilmiştir. Hemen her sayısında yurt insanının ve gençliğin kültür hayatı ile ilgili içerikler yayımlanmıştır. Özdilek, Türk Ocağı düşüncesinin yanı sıra edebî ve ilmî yazılara da yer vermiş ve cumhuriyet düşüncesinin yayılmasında oldukça önemli rol oynamıştır. Aynı zamanda devrimlerin yoğun olarak yapıldığı bu dönemde, söz konusu devrimlerin özellikle gençler tarafından benimsenmesi ve desteklenmesine yönünde faaliyetlerde bulunmuştur. Dergi çerçevesinde dönem içinde yapılan konferanslar, konferansı veren yetkililer üzerinden değerlendirilen hususlar vasıtası ile eğitim ve öğretimin gündemi değerlendirilmiştir. Maarif vekâletince çıkartılan nizamnamelere de yer verilmesi, derginin önceliğinin eğitim işlerinin olduğunun da bir kanıtı niteliğindedir. Bu çalışmada; zor bir dönemde yayın hayatına giren, edebî ve ilmî bir dergi olan Özdilek'in Trabzon ve çevresindeki eğitim ve öğretim haberleri, düşünceleri ve yazıları incelenmiştir. Amaç, eğitim haberleri, sorunları ve dersleri inceleyerek, yeni eğitim ve maarifin görevleri aracılı̆̆ ile o döneme 1 şık tutmaktır.

Anahtar Kelimeler: Mecmua Trabzon, Özdilek, Eğitim Tarihi.

\section{Giriş}

Trabzon ve çevresi yayın hayatı olarak zengin bir içeriğe sahiptir. (Albayrak, 1994) Özdilek mecmuasının basıldığı İstiklal matbaasının Trabzon'un kültür hayatına büyük hizmetleri olmuştur. 1920 yılında Faik Ahmet Barutçu'nun İstanbul'a giderek aldığı matbaa makinesi ve diğer malzeme ile Sakız meydanında Barutçuzadelere ait binada kurularak hizmete başlamıştır. (Albayrak, 1994:639)

Devrimlerin gerçekleştirilmesi ve cumhuriyetin kuruluşu aşamasında Özdilek mecmuasının Trabzon'a gelmesi ile birlikte şehrin basın hayatı yeni bir renk kazanmıştır. (Koloğlu, 2006; Yalçın, 2010) Aynı zamanda devrimlerin yoğun olarak yapıldığı bu dönemde derginin imtiyaz sahibinin öğretmen olması hasebiyle dergi, özellikle gençlere hitap etmiş; Cumhuriyet devrimlerini benimsenmelerine ve bu devrimlerin yanında yer almalarına yönelik faaliyetlerini devam ettirmiştir.

"Özdilek; eğitim-öğretim hayatımızın ve devrimlerimizin en esaslı ve ruhlu konuların oluşturan toplu ögretim, hayat bilgisi, sözcük yöntemiyle alfabe, eğitim sistemleri ve disiplin araçları konularına, gücü oranında epeyce değinmeyi gerekli görmüş̧ür. Bu konuların uygulama sahnesindeki değerlerini yerel kurallara uygun olarak yapılacak plan ve müfredat programlarının şekillerini ve ana hatlarını göstermeyi bir görev anlayışı olarak kabul etmiştir...”(C:K, 1339:35) Derginin amacını açıç̧a belirten bu ifade ile birlikte eğitim ve öğretim müdürlüğünün de önemi ve etkisi vurgulanmıştır. (Yolalıcı, 1994: 435-473; Piyale, 1988)

Özdilek mecmuası yazarları, yol haritalarını, eğitimle ilgili konuları içeren düşüncelerini yazmak, pedagojik uygulama deneyimlerinden aldıkları sonuçları işleme koymak zorunda olduklarını ifade etmektedirler... "Yetiştirmek üzere aldığımı çocukları Türk topluluğuna ve hayata tekrar iade ederken bu çocukların; bugünün ve özellikle yarının gereklilikleriyle, zorunluluklarıyla kolayca yaşayabilecek, olgunlaşma yolunda başarlyla yürüyebilecek bir kitlenin hayatına can verebilecek değerli birer unsur olmalart, en çok dikkat etmemiz gereken konudur”. (C.K, 1339:36)

Özdilek Dergisi’nin yayın müdürü Cemal Gültekin, amaçlarını "Büyük inancımızın ilâhi düsturlarından güç ve kuvvet alarak Türk çocuğunu heyecanlı bir vatandaş, iyi bir üretici, ateşli bir cumhuriyetçi ve hayatın her türlü zorluk ve sikıntılartyla mücadele edebilecek ve bu mücadelede galip gelecek yaratıcı karakterler yetiştirmektir." (C.K, 1339: 35,36) Cemal Bey'in eğitimci kişiliğinin yanı sıra, Atatürk devrimlerinin savunucusu olması, dergide de izlerini göstermiştir. 
Özdilek Dergisi, yola çıkış amacı ve uygulama olarak eğitim işlerini ve eğitimci yetiştirmeyi görev edinmiş, devrimlerin yoğun olarak yapıldığı bu dönemde yeni fikirleri destekleyici bir rol üstlenmiştir. (Revnakoğlu, 1961:227, 228). Bu çalışmada, derginin, eğitim ile ilgili yazıları, eğitim ve ögretim sorunları konusundaki tespitleri incelenecek ve bu sayede dönemin eğitim anlayışına dair bir çerçeve oluşturulacaktır.

\section{1. Özdilek Mecmuasında Eğitim ve Öğretime Dair Önerilerden Bir Örnek: Resim Dersi}

Mecmua yazarlarından Mehmet Hüsnü kaleme aldığı "Eğitimden Kasıt" adlı yazıda (Hüsnü, 1339: 38-41) "eğitimi etkileyen şeyler ĕgitimcilerin, ebeveyn ve ögretmenlerin yönelttikleri etkiler çevrenin etkilerinden azdır. Çocuk, topluluk ve çevreden gelen etkilere çok açıktır." diyerek eğitime etki eden unsurlara dair bir değerlendirmede bulunmuştur.

Söz konusu yazıda ilkokullarda verilen resim dersinin amacının, öğrencilere terbiyeyi öğretmek olduğu ifade edilmiştir. Bunun sebebini ise, okullarda çocuklara verilmesi gereken terbiyenin zemininin resimle daha kolay kavramsallaştırılacağı düşüncesi oluşturmaktadır. (Hüsnü, 1339:38-41) Resim dersinin işlenişine dair verilen ayrıntılar ise şöyledir:

"Öğretmen, tahta üzerine çizdiği çizgilerin aynen defterlere de çizilmesini söylemiş ve resim dersi, düşünmeyi gerektirmeyen çok kolay bir uğraş zannedilmiştir" ifadesi kullanılmıştır. Öğretmen tarafından bir takım basılı örnekler verilerek kopya ettirilmiş, canlı hayvan ve insan resimleri çizilmesi reddedilmiştir. Resim dersinin, her şeyden önce diğer derslerin gelişmesine ve anlaşılmasına aracı olması gerektiği vurgulanmıştır. Resim dersi işlenirken, öğrencinin ilgiyi kaybettiği andan itibaren sınıfta düzenin bozulacağı belirtilmiş, dersin öğretmeninin öğrencilerin dikkatini çekmeyi amaçlayan, ilgi çekici sözler, durumlar ve şekiller icat ederek çocuğun dersten yararlanmasını ve derse odaklanmasını sağlaması gerektiği vurgulanmıştır. (Hüsnü, 1339:38-41)

Resim dersi eğer açık havada veya bahçede verilirse çocuklara temiz hava almayı, nesneleri yerinde incelemeyi, göremediği noktaları kendi elleriyle dokunarak inceleme yapmaya alıştırdığ gibi ilginin oluşmasını sağlamak da mümkün hale geleceği zikredilmiştir. (Hüsnü, 1339:38-41) Resim dersi aracılığı ile çocuğu baktığı nesne üzerinde görmeye, düşünmeye ve incelemeye alıştırmak için öğretmenin resim dersine ihtiyaç duyacağı söylenmiştir. (İlk Tedrisad Müfettişi Hikmet: 45-49) Resim dersinin, öğrencilerin bir şey ortaya koyma yeteneklerini geliştirdiği, dikkatini toplama ve inceleme yönlerini geliştirdiği hem de bir disiplin kazandırdığı örnekler üzerinden anlatılmıştır. (İlk Tedrisad Müfettişi Hikmet: 45-49).

Resim ve el işleri dersini alan bir çocuk Trabzon Erkek Öğretmen Okulu'nda görevli El İşleri öğretmeni Veysel Faik tarafından ise şu şeklide tasvir edilmiştir:

"Bir sanatkârı üzerinde derin derin düşündüren bir yaprak çocuk için beyaz bir daireden ibarettir. Bir ăgacı çocuk da tahayyül eder. Âlemde tahayyül eder. Bir sanatkâr ve bir ressam da tahayyül eder. Şüphesiz her birinin düşünce, görüss ve kabiliyetleri ayrı ayrıdır. Iş̧ mektebi muallimi, resmin tedrisi bir klymet alan cihetini nazar-ı dikkate alarak muhakematın, tedrisatını ona göre uydurması lazımdır." (Trabzon Erkek Muallim Mektebi El İşleri Muallimi Veysel Faik: 42-44). Öğretmen Veysel Faik'in de ifade ettiği gibi yeteneğe dayalı dersler öğrenciler için bir nevi dünyaya açılış kapılarıdır.

Mecmua yazarlarından öğretmen F.S.'ye göre, ulaşımı sınırlı memleketlerin sahilinde bulunan okullar için kum, güzel bir öğrenme aracıdır. Çocukların ruh durumlarına uygun ders verilebilmesi için bu araçtan mümkün olduğunca çok yararlanılması gerekmektedir. Hiçbir amaç gütmeden çocuklar kayıtsız şartsız kumlarla oynamaya terk edildiği zaman, öğrencilerin kum üzerinde bizim hayal bile edemeyeceğimiz çeşitli oyunlar üreterek çok değişik işler yaptı̆̆ görülmektedir. Kumdan; öğretmenin zekâ ve yeteneğine, düşünce üretimine, çocuğun ruh durumuna ve dersin konusuna göre değişmek üzere pek çok işler yapılabilmektedir. (F:S:4-30) 


\section{Yeni Eğitim Yurtlarımız ve Görevlerimiz}

"Biz kendimizi, geçmişin körelttiği bugünkü varlığımızı atölye ve sahalarda keşfetmek ve geliştirmek gibi büyük bir işin çok önemli sorumluluğuna adamış insanlarız. Biz, uzun müddet bakar kör yaşatılan, körleştirilen kişiliğimizi, yeni bir eğitim sistemiyle esaslı ve çok canlı bir hayata geçirmek istiyoruz. Bu çok önemli ve hayati konularda çok önemli ve radikal rolleri üstlenmek zorundayız...". (Muallim Baha Tevfik: 50,51)

Özdilek mecmuasının 9-35 numaralı sayısında öğretmen Baha Tevfik tarafından kaleme alınan "Yeni Eğitim Yurtlarımız ve Görevlerimiz" adlı yazıda, dönemin özelliği ve görevlerin tespitini şu sözlerle anlatmaktadır: "Bizim için viraneyi bayındıra çevirebilecek, yıkıcı değil daha çok yapıcı bir neslin hemen ve ivedilikle yetiştirilmesi gereklidir. Bugün her bireyimizi üretici yapmanın yollarını aramak; çaresizliği, tembelliği o karanlık tarihiyle beraber hemen yere gömmek ve bu işleri en kısa bir sürede yapmak zorundayız. Yaratacağımız yeni dünya, yepyeni bir eğitim sistemine şiddetle ihtiyaç duymaktadır. Eski eğitim sistemimizle bu yeni yolda yürümemize imkân yoktur”. (Muallim Baha Tevfik: 51).

Mecmua yazarlarından öğretmen Baha Tevfik yine aynı yazısında Türk milletinin önemli ve büyük yeteneklere sahip olduğunu belirterek Yeni yetişecek nesil, fen ve sanat dünyasında büyük harikalar yaratmakla ve yaşatmakla sorumlu ve bunun için de garplıları yetiştiren terbiyeyi biz de tamamıyla almak istemekteyiz sözlerini sarf etmektedir. Baha Tevfik'in yazısının devamında Yeni nesil, yeni terbiye yurtlarında yetiştirerek, doğayla, nesnelerle yarışıp, zevk ve neşe içinde, yargılama, akıl yürütme ve yaratma faaliyetlerine koyulur. (Muallim Baha Tevfik: 50, 51)

Yine aynı köşe yazısında Tevfik, çalışma odalarında çocukların birbirini tamamlayarak çalıştı̆̆ını dile getirmiştir. Kısa bir sürede okulların, bu yeni temeller üzerinde gelişerek yeni nesli, milletin emellerini ve gücünü yükseltecek bir şekilde yetiştirmeye yarayacak birer eğitim yurdu olacağını tüm inançlarıyla ümit ettiklerini yazmıştır. (Muallim Baha Tevfik: 50-54)

\section{Okuma Yazma Eğitiminin İşleyiş ve Uygulamalarına Dair Tespit ve Öneriler}

Okuma yazma kursunda, ilk okuma derslerinin yöntem ve uygulama öğretmeni olan Baha Tevfik Bey'in mecmuaya yazdığı önsözden alınan bazı tespitler şu yöndedir:

1. Okuma işlerinde bugüne kadar çok kötü, çok yanlış bir düşünce biçimi hâkimdir ve sadece telaffuzdan (söyleyiş) ibaret olduğu düşünülmüştür. Eski düşünce yapısında çocuğun birinci sinıfta her sözcüğü öğrenmesi, bunun için de hepsini öğretebilecek bir yöntem olması istenmiştir. Uzun bir süre bu arayışta olup bir çözüm bulamamışlar çünkü lisanda (dilde) böyle bir yöntem hiç var olmamıştır. (Muallim Baha Tevfik: 50-54)

2. Okumak, başkalarının yazılı düşüncelerini okuyup kavramak demektir ve çocuğa ancak kavrayabileceği şeyler okutmalıyız. Bugünkü görüş ve inancımızla deriz ki çocuk için basit olan harf değil manayı anladığı ve ilgilendiği sözcük ve cümlelerdir. Çocuğun okuyacağı cümlelerin, genellikle kendisini ilgilendirecek bir niteliğe sahip olması gerekmektedir. Seçilecek cümleler ve sözcükler çocukların, çevrenin ve ihtiyaçların diline uygun; ilgi ve heves oluşturacak değerde olmalıdır. (Muallim Baha Tevfik: 53,54).

Öğretmen Okulu Yazı Öğretmeni Veysel Faik ve Baha Tevfik okuma yazma konusunda şu öneri ve tespitlerde bulunmuşlardır:

1. İlköğrenim; mahalle aralarındaki camiye bitişik, tek odalı yerlerde çocukları rahleler önüne dizerek verilirdi.

2. Çocuklara ilkokulda anlayabilecekleri öyküler vermeli, öğretmenin görevi ise bunu uygulamak olmalıdır. ( Faik-Tevfik: 71-73) 
3. Kitapçılık eğitimini atarak hayatçılık eğitimine başladığımız şu günde, yeni hayata yeni nesil yetiştirmek ve yeni nesle yeni eğitim vermek zorundayız. Çünkü toplum kendi sağlık güç ve ülküsüne göre hazırlanmış adam istemektedir.

4. Bugünkü okul, bizzat amaç değil araçtır. Hayatın şartlarına uyum sağlayan ve toplumun ihtiyaçlarına cevap veren sözcük yerine nesneyi, kitap yerine hayatı inceleyen ve cumhuriyet vatandaşı hazırlayan, çocuğun kendi kendine yeterli olması, üretken bir vatandaş olması için iş prensibi kabul eden çocuğun olgunlaşmasına saygı duyan doğa faaliyetlerine genel akım veren bir kurumdur.

5. Siyasi devrimimizin gerektirdiği eğitim ve öğretim devrimi, halkımızı layık olduğu mutlu ve olgun amaca ulaştırmak için köklü ama bilinçli bir hareket olarak ortaya çıkar. Bugün öğretimimiz nasıl yaşam ve doğadan faydalanıyorsa eğitimimiz de milliyete, milli bir duruşa, ülküye, gerçekliğe, inanca dayanan bir varlığa yaslanacaktır. Öğretimimizle de hayati işler terbiyemizle de aydın ve bilgili insan yetiştirebiliriz. Böyle bir insan, sataşma veya saldırıya uğrayan, geçmişe çok düşkün, yazgıya sessizce boyun eğen insan demek değildir. (Faik-Tevfik:71-73)

\section{Maarif Emanetince (Eğitim ve Öğretim Kurumunca) Cumhuriyet Halk Fırkası Salonunda ve Öğretmenler Birliğinde Verdirilen Konferanslar}

Özdilek mecmuasının, 10-35. sayısında maarif emanetince Cumhuriyet Halk Firkas1 salonunda 1927 'de verilen bir dizi konferansın konu, kişi ve tarih bazında listesi verilmiştir:

\begin{tabular}{|c|c|c|}
\hline Konu & Konferansı Veren & Tarih \\
\hline $\begin{array}{l}\text { 1. Türkiye Cumhuriyeti Halk } \\
\text { Firkasının Eğitim ve Öğretim } \\
\text { İlkeleri }\end{array}$ & Maarif Emini Tevfik Beyefendi & 27 Kanun-u evvel \\
\hline $\begin{array}{l}\text { 2. İnk1lâp ve Medeniyet } \\
\text { Tarihinde Türkler }\end{array}$ & $\begin{array}{l}\text { Lise Edebiyat Muallimi Orhan Riza } \\
\text { Bey }\end{array}$ & 2 Kanun-u evvel \\
\hline $\begin{array}{l}\text { 3. İtikatlarımızın Sebep ve } \\
\text { Menşei }\end{array}$ & $\begin{array}{l}\text { Lise ve Muallim Mektebi Felsefe } \\
\text { ve İçtimaiyat Muallimi Arifan Bey }\end{array}$ & 9 Kanun-u evvel \\
\hline $\begin{array}{l}\text { 4. Türkiye Cumhuriyeti ve } \\
\text { Cumhuriyetin Ekmel bir Tarz- } \\
1 \text { İdare Olduğu }\end{array}$ & $\begin{array}{lcc}\text { Lise Tarih } & \text { Muallimi } & \text { Mustafa } \\
\text { Mümtaz Bey } & & \end{array}$ & 16 Kanun-u evvel \\
\hline $\begin{array}{l}\text { 5. Emraz-1 Zehriye ve } \mathrm{Bu} \\
\text { Marazın Memleketimizdeki } \\
\text { Vaziyeti }\end{array}$ & Doktor Operatör Ömer Bincan Bey & 23 Kanun-u evvel \\
\hline $\begin{array}{l}\text { 6. Kızlarımızın Talim Ve } \\
\text { Terbiyesi }\end{array}$ & $\begin{array}{l}\text { Lise Riyaziye Muallimlerinden } \\
\text { Osman Galip Bey }\end{array}$ & 30 Kanun-u evvel \\
\hline 7. Arap Edebiyat1 & Şair Cenah Muhiddin Bey & " \\
\hline $\begin{array}{l}\text { 8."Hamsi"Nin Bu Havalideki } \\
\text { Kiymet Ve Ehemmiyeti }\end{array}$ & $\begin{array}{l}\text { Ticaret Mektebi } \\
\text { Hamamizade İhsan Bey }\end{array}$ & " \\
\hline 9.Niçin ve Nasıl Vergi Veririz & $\begin{array}{l}\text { Lise ve Muallim Mektebi Felsefe } \\
\text { Muallimi Arifan Bey }\end{array}$ & 27 Kanun-u evvel \\
\hline $\begin{array}{l}\text { 10. Ziraatın Evlerdeki } \\
\text { Tatbikatı "Tavukçuluk" }\end{array}$ & $\begin{array}{l}\text { Muallim Mektebi Vekili Muallimi } \\
\text { Niyazi Fehmi }\end{array}$ & 13 Kanun-u evvel \\
\hline 11. Son Asırda Türkiye Tarihi & $\begin{array}{l}\text { Lise Tarih - Coğrafya Muallimi } \\
\text { Mustafa Mümtaz Bey }\end{array}$ & 3 Şubat \\
\hline $\begin{array}{l}\text { 12. Harflerimiz ve Latin } \\
\text { Harfleri }\end{array}$ & Lise Türkçe Muallimi Recai Bey & 7 Şubat \\
\hline 13. Meslek Terbiyesi & $\begin{array}{l}\text { Muallim Mektebi Felsefe Arifan } \\
\text { Bey }\end{array}$ & 10 Şubat \\
\hline
\end{tabular}


Tabloda da görüldüğü üzere, konferans düzenleyicilerinin tamamı eğitimcilerden oluşmakta ve konuşmaların ana odağı cumhuriyet ideolojisinin benimsetilmesi amacıyla halkın eğitimi konusu olmuştur. Ayrıca Cumhuriyet ideolojisinin benimsetilmesi kadar önemli görülen hususlar mesleki eğitim ve Türk tarih ve kültürü hakkında bilgi ve bilinç verme de bulunmaktadır. (Tevfik,1927:1035)

\section{5. Öğretmenler Yardım Ocağı ve Tüzüğü}

Mecmuanın 10 Temmuz 1339 tarihli sayısında muallimler için bir yardım ocağı kurulması ve nizamnamesinin detayları yer almıştır. Bazı muallimlerin teșebbüsleri ile memlekette "muallim yardım ocağı" namıla hakiki ve müsmir (netice veren) gayeleri istihdaf etmek (hedeflemek) üzere bir cemiyet tesis edileceği memnuniyetle haber alınmıştır. (Turgut,1339:95,96) Muallimler Yardım Ocağı nizamnamesi, 22 ana maddeden ve A harfinden $\mathrm{N}$ harfine kadar ana başlıklardan oluşmaktadır. 8. maddede genel kurul, yönetim kurulu ve örgütlenme esasına yer verilmiştir. Çalışan ve yardımcı üyelere dair bilgiler ve tüm üyelerin görev ve yetki tanımları bu nizamname çerçevesinde belirlenmiştir. (Turgut, 1339: 95,96)

\section{Tatil Zamanında Verilen Eğitim: Tatil Dershaneleri}

Tatil Dershaneleri, memlekette erkek öğretmen okulundan mezun olmayan öğretmenlerin ilim, yönetim ve eğitim eksiklerini tamamlamak ve bu öğretmenlerin bağlılıklarını, anlayış ve anlama yeteneklerinin öğretmenliğe uygun olup olmadıklarını anlamak ve varsa eksiklerini tatil dersinde telafi etmek için açılmıştır. (Gültekin, 1340: 1-4)

$\mathrm{Bu}$ dershanelerin amacı ise öğretim yönteminin yeni ve verimli yollarını eğitim ve hayatın fiili ve inanış noktalarını, ödül ve ceza yöntemlerini, çocukları yönetme sanatının kolaylıklarını açık ve net bir şekilde konuşarak öğretmen olmak isteyen meslektaşlara aktarmaktır. Memlekette öğretmen yokluğu sürdükçe Tatil Dershaneleri adındaki bu kursların sürdürülmesi bir zorunluluktur. İmtiyaz sahibi ve öğretmen yazar Gültekin'e göre Her ne kadar okuyanla okutanın akıllar doldurulmuş ise de eğitim ve ögretimdeki eksiklerimizi gidermek için fazla çalışmak zorundayız. Bugünün ögretmenlerine memleketin ilim ve hikmet durumu adına büyük görevler yüklenmektedir. (Gültekin, 1340: 1-4)

Erkek öğretmen okulundan çıkacak öğretmenlerin miktarı memleketin öğretmen ihtiyacını karşılayacak düzeye geldikten sonra bile Tatil Dershaneleri'ne devam edileceği kesindir ifadesi kullanılmıştır. Yaz vakti içinde ilköğretim öğretmenlerinin her gün bir derece daha fazla çalışmasına ihtiyaç duyulmakta olduğundan yaz derslerinin zorunlu olması uygun görülmüştür. Yaz derslerinin işleyişleri hususunda, derslerin nasıl, nerede ve hangi teneffüs düzeni ile yapılacağı, çocukların ruhî ve bedenî yeteneklerinin geliştirilmesi için öğretmenin neler yapacağı gibi noktalar belirlenmiştir. Belirlenen bu esaslara göre öğretmen, öncelikle kendi köyünde ve çevresinde öğretmen olur. Bu yaz kurslarındaki öğretmenlik, normal eğitim süresindeki öğretmenlikle aynı olmamaktadır ve bunun esasları şu şekilde ifade edilmiştir:

1. Tatil derslerine devam eden ögretmenler, orta ve lise mezunu veya lisenin on, on bir ve on ikinci sinıfindaysalar sadece meslek derslerine, fen eğitimi, ahlak ziraat kimyast derslerine devam ederler

2. Tatil Dershaneleri, iki sinıf olarak birbirine bağlıdır. Birinci sinlfa ibtidai ve rüsdiye mezunlart ve yetki belgeleri olan ögretmenler dâhil olurlar. Bunların seviyeleri arasinda büyük farklar olmadı̆̆ kanaatindeyim, bu hususu deneyimlerim göstermiştir. Bu ögretmenlere meslek dersleriyle beraber hesap, geometri, Türkçe, hayvanlar, bitkiler, ziraat, hikmet ve kimya gibi dersler verilir.

3. İkinci sinıfa ve üç sinıflı Öğretmen Okulu mezunları, hazırlığın son sinıflarl, lisenin birinci dönemindekiler kaydedilir. Bu sinıfta da yine meslek dersleri ve birinci sinff derslerine ek olarak cebir, hukuk bilgileri ve iktisat dersleri ve gökbilim yöntem defteri verilir. 
4. Bu derslerin Öğretmen Okul ögrretmenlerdeki müfredat programı yönüyle ögrretim tamamlama şart değildir. Öğretmen, bu derslerin en anlamlı noktalarını ögretmenlere anlatacak, onlar da boş zamanlarında ve gece okumalarında bu derslerdeki eksikliklerini sorup ögreneceklerdir. Bu derslerden her ögretmenin, seviyesi yetenekleri oranında yararlanmasl gayet doğaldır. Bir tatil dersinde eksiğini tamamlayamayan bir ögretmen, ikinci tatil dersinde tamamlamaya çalışır.

5. Tatil dersleri, öğretim topluluğunu kursu takip edip devam edenlerin yeterliliklerini yoklar; heröğretmenin konuşma biçimi nasıl, anlama ve kavraylşı ne derecede, öğretimden ne kadar yararlanmıştır, bilgi olarak ve ders yöntemiyle eksiklerini kaç tatil dersinde tamamlayabilir, bunları kontrol eder. Bu gibi konular hakkında öğretim daireleri bölgeleri içindeki öğretmenler hakkında elbette daha açı, net, olumsuz olan ve kesin fikirler edinirler

6. Okuyan öğretmenle okuyan meslektaşın seviyelerinin uygun olduğu da söz konusu olamaz. Lise ve erkek ögretmen okulları eski şeklinde kalmış olsaydı bu düşünce doğru olabilirdi. Fakat bugün okullarda seçilen ve atanan ögretmenler vekâletçe tanınmış kişiler olduğu gibi verdikleri derslerinde uzmanidirlar.

7. Öğretimden sonuç olarak yararlanılıp yararlanılmadı̆̆ını iddia etmek bu konuda yapılacak istatistikî bilgilere ve deneyime bağlldır. Ben ve arkadaşlarım bu derslerin sonucundan ve almış olduğumuz cevaplardan memnun olduğumuz gibi muhasebelerimizde bulunan ve yöntem ve yönetimimize daha yakından temas eden arkadaşlarımız da yararlanma derecesindeki büyüklüğü canı gönülden ögretmenlerine açıklamışlardır.

8. Kız ve erkek ögretmen okullarından şimdiye kadar altı tatil dersine iştirak ettim, okuyan ve okutan arkadaşlarımın memnun ayrılması bu düşüncemizi doğrulamakta ve onaylamaktadır. Dolayısıyla tatil derslerinin devamını memleketin mutlu ve huzurlu geleceği adına dilerim. (Gültekin, 1340:1-4)

Yaz kursları ve derslerin verilme esasları düşünüldüğünde amacın devrimlerin yoğun olarak yapıldığı bu dönemde çocukların okullardan uzak kalmamasını sağlamak, eğitimlerine devam edilerek gelişimlerini sürdürmek olduğu görülmüsstür. Bu amaçtan hareketle öğretmenlere önemli görevler yüklenmiştir.

\section{Hıfzıssıhha Mekâtibi (Sağlık Bilgisi Okulları)}

Bir müdür veya öğretmenin öğrencilerine karşı görevi yalnızca öğretim vermek değil, onların sıhhatini de korumakla sorumlu olduğunu bilmektir. Bu durumdan hareketle, Derginin 1 Eylül 1340 tarihli sayısında Ali Haydar, tarafından kaleme alınan "Hıfzıssıhha Mekâtibi" (Sağllk Bilgisi Okulu), yazıda sağlı̆̆ın ve okulların önemine dair tespitlerde bulunmuştur. Yazıda çocukların sağlığının yalnız okulda değil, okul dışında da takip edilmesi ve korunması gerektiği ifade edilmiştir. Sebebi ise, okulda veya dışarıda çocukta ortaya çıkacak bir hastalığın aileyi ve memleketi de tehdit edebileceği şeklinde açıklanmıştır. Bugünün çocuğunun, yarının babası olduğundan bahsedilmiş ve sağlıklı gençlerin ülkenin geleceği olduğunun altı çizilmiştir. (Haydar, 1340:5)

Dergide, okul sağlığı, okul, yapının görünüşü, dershane, hava değişimleri, aydınlatma, temizlik, abdesthaneler ve su gibi konularda Ali Haydar tarafından detaylı bilgiler verilmiş, temizlik üzerinde özellikle durulmuştur. (Haydar, 1340: 5)

\section{Yeni Müfredat Programı Hakkında Bir Konferans}

Yeni müfredat programları hakkında meslektaşlar arasında konuyu tartışmak, daha iyi kavramak amacı ile konferans düzenlendiğinin bilgisi de verilmiştir. Ders sorumlusu müdür ve öğretmen Cemal Gültekin'in kaleme aldığı yazıda, konferansa yazarlardan Baha Tevfik'in davet edildiği görülmektedir. Konferansın içeriğinin bir kısmı yeni eğitim öğretim sistemi olmakla birlikte, diğer bir konu ise aile içi rollerin icrası olmuştur. Bunun yanında, müfredatın keyfilikten çıkıp belirli bir çerçeve çizerek, tahsil çağındaki çocuklara verilecek bilginin belirlenmesi ve sınırlarının oluşturulması olmuştur. 
"Yalnız bir nokta kalıyor ki o da çocuklara vereceğimiz bu bilgiyi hangi hedef ve amaçlar gözeterek vereceğiz? Öğretimimizin çocuk için daha kullanışlı daha hayati olması ne ile mümkündür? Derslerin uzun süre hafizalarda kalabilmesi için hangi yollardan gideceğiz? Işste bu elimizdeki yeni müfredat programları yine psikoloji kanunlarındaki çıkarımla fiili sonuca gidecek miyiz? Aklımız, denilebilir ki dünyadaki makinelerden daha karmaşık olduğu gibi içindeki bağlarıla sonsuz ilerleyişiyle çok muntazam işleyen bir makinedir. Buraya girecek olan bilgiler bu bağların hepsini işletecek ve harekete geçirecek tarzda olmalıdır. Buraya girecek olan bilgiler zihnin derinliklerinde iyice sağlamlaşana kadar ne kadar çok tekrar edilebilirse o bilgiler bilinç yüzeyine o kadar kolaylıkla çıkar. Düşüncemizi anlatabilmek için şöyle diyebilirim ki bir fabrikanın bütün çarklarının diğerine bağlı olarak işlerse zihne girecek olan bilgiler de deyim yerindeyse onun bütün çarklarını işletecek tarzda ilgili ve bağlantılı olmalıdır. Bunun yanı sıra băglantı görevini yapan çağrışımdır. Mesela limon fikrine sahip olmamı için bu meyveden gelen zevki, ekşilik tadl, koku itibariyle diğeriyle birleşmelidir. Sonra rengi, şekli, sesi, zihninde bağlantı oluşturmadıkça da kuş fikri de bizde hâsıl olmaz...)”. (Gültekin, 1927:10-12)

Hayat bilgisinde düşündürdügümüz şeyleri el işleri dersinde de düşündürmesi gerektiği ifade edilmiştir. Çocuğa yaptığı işi düşünme fırsatı vererek, bir bilginin aynı zamanda kendisinin malı olmasını ve onu kullanabilmesini sağlamak amaçlanmıştır. Çocuğun yeni müfredat çerçevesinde aldığı bilgiyi kullanmasını sağlamak başlıca gaye olmuştur. Bu amaç ve düşünceler etrafında yeni öğretimin hedefleri şu şekilde ifade edilmiştir:

1. Çocuğa çevresindeki nesneler incelettirilecek ve bu nesnelerin fazlaca olması sağlanacaktır. edecektir.

2. Çocuğun etrafinda meydana gelen her olay, verilecek olan dersimizin konusunu teşkil

3. Çocuk bu nesneler ve düşünceleri resim ve el işleri aracıliğ ile çizecek ve yapacaktır.

4. Çocuk bu çizdiği ve yaptı̆̆ı nesneleri okuyacak ya da anlatacaktır.

5. Çocuğa bu nesneler ve olayların hesabını ve ölçüsünü yaptıracă̆ız.

6. Çocuğa bu nesneler ve olayların zevkini duyuracak şarkılar söyleteceğiz. (Gültekin, 1927:

10-12)

Sonuç olarak çocuk görecek, tadacak, inceleyecek, araştıracak, yapacak, bozacak, yaptığını ve bozduğunu anlatacak, derslerin canlı ve uyumlu konuları içinde yaşayacak ve yaşatacak olduğu anlatılmıştır. Eğer işlenen derslerin bu yönde verilmediği gerçeği varsa, o dersin hayati, ilmi, eğitimsel açıdan toplam bir kıymeti olmadığı vurgulanmıştır.

Baha Tevfik'in konferansta ifade ettiği başka bir konu ise, derslerin çocuklara uygun olması ve yaratılış ve insani ilgilerinden yararlanılması konusunun gereğidir. Çocuğun ilgi duyduğu alanlar için görevler verilerek derse ilgi arttırılmalıdır diye ifade etmiştir.

“...Çocuğun psikolojik faaliyetlerini can sıkıcıydı gibi bütün karşıllklı görüşmelerin açığa çıkıp bilinmesini sağlayan tek araçtır. Eski müfredat programında her öğretmen kendi dersinde çocuğu kendi istediği bir hedefe yönlendiriyordu. Hâlbuki yeni yöntem öğretim ve müfredat programı dikkat ve özenle uygulanacak olursa okulun tüm öğretmenleri çocuğu belirli bir hedefe birlikte sevk edecekler. Bu şekilde, çok güçlü bir hastallklı üründen, tam, gerçek ve kusursuz bir ürün elde edilecektir...”.(Gültekin, 1927:10-12)

\section{Sonuç}

Trabzon ve havalisi Osmanlı'dan Cumhuriyet'e taşınan dönemde zengin bir neşir yelpazesine sahiptir. İnkılapların gerçekleştirilmesi ve Cumhuriyetin kuruluşu evresinde Özdilek Mecmuasının Trabzon İstiklal Matbaasında faaliyete devam etmesi ile yayın hayatı daha da zenginleşmiştir. Devrimlerin yoğun olarak yapıldığı, yeni teşkilatlanan bir devletin yapılanması zorluğu arasında dergi de yayın etiği ve ilkesine uygun olarak bir rol üstlenmiştir. Bilhassa genç okuyuculara hitap eden mecmua, Cumhuriyetin getirdiği yeniliklerin benimsenmesi ve onların bu devrimlerin yanında yer almalarına yönelik yayın faaliyetlerini devam ettirmiştir. Bu misyon mecmuanın ana görevi olarak görülmüş ve bunun tesis edilmesi için araç olarak kullanılmıştır. 
$\mathrm{Bu}$ düşünce mecmuanın 1339 senesi 9-35 sayılı yayınında "Uygulama sahnesindeki değerlerini yerel kurallara uygun olarak yapılacak plan ve müfredat programlarının şekillerini ve ana hatlarını göstermeyi bir görev anlayışı olarak kabul etmiştir..." olarak belirlenmiştir. Mecmuanın gayesini net şekilde belirten bu ifade ile birlikte eğitim ve öğretim müdürlüğünün de önemi ve etkisi vurgulanmıştır.

Muallim ve yazarlar, eğitimle ilgili konuları içeren düşüncelerini yazmak, pedagojik uygulama deneyimlerinden aldıkları sonuçları işleme koymak zorunda olduklarını şöyle ifade etmişlerdir "Yetiştirmek üzere aldığımı çocukları Türk topluluğuna ve hayata tekrar iade ederken bu çocukların; bugünün ve özellikle yarının gereklilikleriyle, zorunluluklarıla kolayca yaşayabilecek, olgunlaşma yolunda başarıyla yürüyebilecek bir kitlenin hayatına can verebilecek değerli birer unsur olmaları, en çok dikkat etmemiz gereken konudur”. Gerekli sayılarda bu yönde yazılar yayımlamışlardır. Mecmua olarak Trabzon ve havalisinde eğitimin gündemini, inkılapları destekler nitelikle yayın hayatına katkı sağlaması, mecmuayı önemli bir yere taşımıştır.

\section{Kaynakça}

Özdilek Mecmuası. (1339). 9-35, Erzurum: Vilayet Matbaas1.

(1339). 5-31, Trabzon: İstiklal Matbaas1.

, 10-35, Trabzon: İstiklal Matbaası.

, (1340). 2/1. Trabzon: İstiklal Matbaas1.

,(1340). 2/2, Trabzon: İstiklal Matbaas1.

, 2/4, Trabzon: İstiklal Matbaas1.

-, 1-27, Trabzon: İstiklal Matbaas1.

, 4-30, Trabzon: İstiklal Matbaas1.

Albayrak, H.(1994). Trabzon Basın Tarihi, I, Ankara: Türkiye Diyanet Vakfi.

C. K. (1923). Özdilek Mecmuasl, 9-35, Erzurum: Vilayet Matbaası: 35-40.

F.S, (1339). “İş Mektebinde Kum İşleri, Özdilek Mecmuası, Özdilek Mecmuası, 9-35, Erzurum: Vilayet Matbaas1: 4-30.

Gültekin, C. (1927). "Yeni Müfredat Programı Hakkında", Özdilek Mecmuası, 5. Trabzon: İstiklal Matbaası: 10-15.

Gültekin, C. (1340). “Tatil Dershaneleri”, Özdilek Mecmuası, 2/2. Erzurum: Vilayet Matbaası: 1-5.

Haydar, A. (1340). "Hıfzıssıhha Mekâtibi”, Özdilek Mecmuası, Erzurum: Vilayet Matbaası: 3-7.22

Hüsnü, M. (1339). “Terbiyeden Maksat, Terbiye ve Tedrisin Münasebeti”, Özdilek Mecmuası, 9-35, Erzurum: Vilayet Matbaasi: 38-45.

İlk Tedrisat Müfettişi Hikmet, (1339). Özdilek Mecmuası, S. 9-35, Erzurum: Vilayet Matbaası: 4550 .

Koloğlu O. (2006). Osmanlı'dan 21. Yüzyıla Basın Tarihi, İstanbul: Pozitif Yayınları.

Muallim Baha Tevfik, "Yeni Terbiye Yurtlarımız ve Vazifelerimiz", Özdilek Mecmuası, 10-35. Trabzon: İstaiklal Matbaası: 50-55.

Muallim Mektebi Yazı Muallimi Veysel Faik- Baha Tevfik, Özdilek Mecmuası, 1-27: 71-76. 
Piyale, M. (1988). Trabzon'da Eğitim ve Kültür Hayatı (1839-1923), Ankara Üniversitesi Türk İnkılap Tarihi Enstitüsü Yayımlanmamış Yüksek Lisans Tezi, Ankara.

Revnakoğlu, C. S. (1961). “Erzurum Matbuatı”, Gazetecilik Enstitüsü Dergisi, 2: Erzurum: 223-229.

Trabzon Erkek Muallim Mektebi El İşleri Muallimi Veysel Faik, Özdilek Mecmuası, 4-30. Trabzon: İstiklal Matbaası: s. 42-48.

Turgut, Ş. (1339), Özdilek Mecmuası, I, Erzurum: Vilayet Matbaası: 95-98.

Yalçın, S. (2010), Türkiye Cumhuriyet'i Tarihinin Kaynakları, Ankara: Berikan Yayınları.

Yolalıc1, E. (1994). "Maarif Salnamelerine Göre; Trabzon Vilayetinde Eğitim ve Öğretim Kurumları", Ankara Üniversitesi Osmanlı Tarihi Araştırma Ve Uygulama Merkezi Dergisi, Ankara: 435-473.

\section{EKLER}

\section{EK:1: Muallimler Yardım Ocağı Nizamnamesi}

Madde 1: Merkezi Erzurum olmak üzere "Muallimler Yardım ocağı" namıyla bir ocak teşekkül etmiştir.

Madde 2: Derneğin amacı öğretmenlerin her türlü refahını sağlamak, maddi ve manevi yönden huzurlu olmalarını temin etmeye çalışmak; yoksul, kimsesiz, hasta ve sakat olan kadın, erkek ve çocukların barınma yiyecek ve giyeceklerini temin etmek; okula devam edenler için kitap sağlamak amacıyla nakit ve eşya yardımı yapmak; derneğin geliri oranında yemek ve sanat evleri, gece derslikleri, halk konferansları salonu açarak çocukların bunlara ilgili yetenekleri gözetilerek öğrenim vermek, Avrupa'ya öğrenci göndermek ve sanat öğretmektir. Sonuç olarak yokluğa, zorluklara ve işsizliğe engel olmaktır.

Madde 3: Derneğin amacı iş yapmak ve hayır için çalışmaktır. Hiçbir zaman hiçbir sebeple siyaset ile ilgili olmayacaktır.

Madde 4: Yaşı 20-80 arasındaki aklı başında erkek ve kadınlar Yönetim Kurulu tarafından üye olarak kayıt olabilir.

Madde 5: Üye kayıt ücreti 20 750 kuruş, taahhüt sözleşmesi 5-10 kuruştan az olmayacak ve fazlası herkesin cömertliğine, iyilikseverliğine ve bırakılacaktır.

Madde 6: Derneğin feshi ya da ortadan kalkması söz konusu olduğunda tutarın verilmesi istenen yere verilmesi ve devredilmesi Yönetim Kurulunun kararıla belirlenecektir.

\section{Örgütlenme Esası}

Madde 7: Dernek üyeleri çalışan ve yardımcı adlarında iki kısımdır.

B- Çalışan Üyeler: Erzurum'da ikamet eden ve toplantılarda bulunması mümkün olan öğretmenler ve diğer insan sever kişiler.

C- Yardımcı Üyeler: Erzurum dışında ikamet eden ve toplantılara katılabilecek öğretmen ve diğer kişiler.

Madde 8: Derneğin iki kurulu vardır. 


\section{1- Genel Kurulu}

\section{2- Yönetim Kurulu}

Madde 9: Genel Kurul, her y1l Temmuz'da olmak üzere bir kez yönetim kurulunun daveti üzerine olağanüstü olarak toplandığg tüm çalışan ve yardımcılardır.

Madde 10: Yönetim Kurulu, Genel Kurul tarafından seçilen on iki kişiden oluşur.

Madde 11: Genel Kurul, Yönetim Kurulunun atayıp duyuracağı adaylar arasından Yönetim Kurulunu seçecek ve kararlarını çoğunluğun onayıyla alacaktır.

\section{Görev ve Yetki}

Madde 12: Genel Kurul, Yönetim Kurulunun daveti üzerine görüşme makamında söylenmesi gereken maddeler hakkında karar alıcı olacaktır.

Madde 13: Yönetim Kurulunun düzenleyeceği gerekçeler tasarısına göre tüzük metni maddelerine değişikliğin eklenmesine veya yeniden düzenlenmesine ancak Genel Kurul yetki verecektir.

Madde 14: Yönetim Kurulu, derneğin faaliyet organı sorumlusudur. Bir başkan, bir ikinci başkan, yazıcı, gişe görevlisi, yönetim memuru, güvenilir diğer üyelerden olup on iki kişidir. Genellikle, seçilen bu kişilerin arasından yine seçimle görev bölüşümü yapacaklardır

B- Başkan: Toplantılarda Yönetim Kuruluna makamları görüşme yerine bildirecek. Maddeler ve konuları inceleyip düzenleyerek takvime dâhil edecek, dernek adına gelen belgeleri inceleme, gönderme ve yönetimde alınan kararları bildirme, sonuç olarak haberleşme belgelerini imzalama yetkisine sahip Temsil Kuruludur ve iki oy sahibidir.

C- İkinci Başkan: Başkan bulunmadığı zaman başkana vekâlet edecek ve vekâlet sırasında başkanın yetkisinde olan görevleri yerine getirecek ve bu hukuka sahip olacaktır.

D-Kâtip: Genel Kurul ve Yönetim Kurulunun aldığı kararların kaydedilmesi, kabul edilecek maddelerin kayıtlarının tutulması, bunları dosyalama yöntemi ile düzenleyerek belirli belgelerin ve defterlerin korunması ve saklanması işlerini itina ile yapacaktır.

K- Gişe Görevlisi: Dernek işlerinin hesaplarını koruma yöntemiyle üzerine görüşlerini kaydedip düzenleyecek, dernek belgelerini teslim almaya ve vermeye, güzelce korunmasını sağlamaya yetkilidir. Yönetim Kuruluna ait yazı ve bildirim olmadıkça kesinlikle para harcamayacaktır.

N- Yönetim Memuru: Derneğin toplantı salonu olan dairenin temizlik ve sağlığa uygunluğundan, düzeninden, eşyaların korunmasından, kısaca bina içindeki işlerin ve bu işlerin nasıl yapılacağından sorumlu olacaktır. Günlük işler yerine getirildikçe ortada kalan eşyayı, defteri gereğince ve dikkatlice Yönetim Kurulu üyelerinden üç kişinin gözetimi altında halefine (kendisinin yerine geçecek olana) teslim edecektir.

H- Güvenlik: Yönetim Kurulu kararıyla derneğe ait dış alım ve satış işleri yapacaktır.

Derginin bir sonraki sayısında ise tüzüğün kalan unsurlarına ve kadrosunun görev tanımları verilmeye devam edilmiştir:

Yönetim Kurulu: Alınan kararlar ve maddelerinde, en iyi şekilde üçte ikilik oranındaki genel emirlerle ilgili karar maddelerinde herhangi bir tavsiye, ihmal ya da tekrar ediş var ise başkanın görüşüne başvuracaktır.

Madde 16: Görevler mümkün olduğunca hemen ve düşünmeden yerine getirilecekse ihtiyaç hâlinde Yönetim Kurulu, görevli memurlar atayabilecektir.

Madde 17: Yönetim Kurulu, derneği kaynakların çoğaltılması amacıyla gösteriler, at yarışları, güreş ve spor karşılaşmaları ve benzer önemli ve yararlı faaliyetlerde bulunacaktır. 
Madde 18: Yönetim Kurulu, dernek üyelerinin ve yerel halkın derneğe bağlılığını arttırmaya hizmet edecek ögütlerde bulunan konferanslar düzenleyip ilanlar, bildiriler, dergi ve risaleler hazırlayacaktır. Aydınlık fikirler oluşturmak amacıyla dernek merkezinde sohbet ve okuma salonları oluşturacaktır. Gazeteler ve yüksek memuriyet broşürleri hazırlanmasını, belirli vakıflarda genele açık olarak bulundurulmasını sağlayacaktır. Okuma salonunun iyileştirilmesine ve fark edilmesine çalışacaktır.

Madde 19: Hesap gereği çalışan üyelerin üçte bir oranında imzalarını içeren ifadeleri üzerine Yönetim Kurulu, Genel Kurulu toplantıya davet edecektir.

Madde 20: Kaynakların izin verdiği ölçüde derneğe ait olmak üzere ehl-i sünnet ve yardıma muhtaçlara resmi yöntemler gereğince rehin bırakma ve kefalet (sorumluluğu üzerine alma) şeklinde yapılacak borçlanmalara başarıyla gözetmenlik edilecek ve yönetilecektir.

Madde 21: İstifa eden ve görevi tamamlanan üyeler yerine Genel Kuruldan en çok oy alan kişi atanacak ve her ay dernekteki yerinden ayrilanların isimleri gerekli olursa ilan edilecektir.

Madde 22: Yönetim Kuruluna seçilecek kişilerin hiç olmazsa ikinci derecede eğitim almış okuryazar, oldukça açık görüşlü ve bilgili, siyasetle uğraşmayan ve zihin yapısı yönüyle saygın olan kişilerin bulunması şarttır. 


\section{EK: 2: ÖZDİLEK MECMUASI KAPAK}
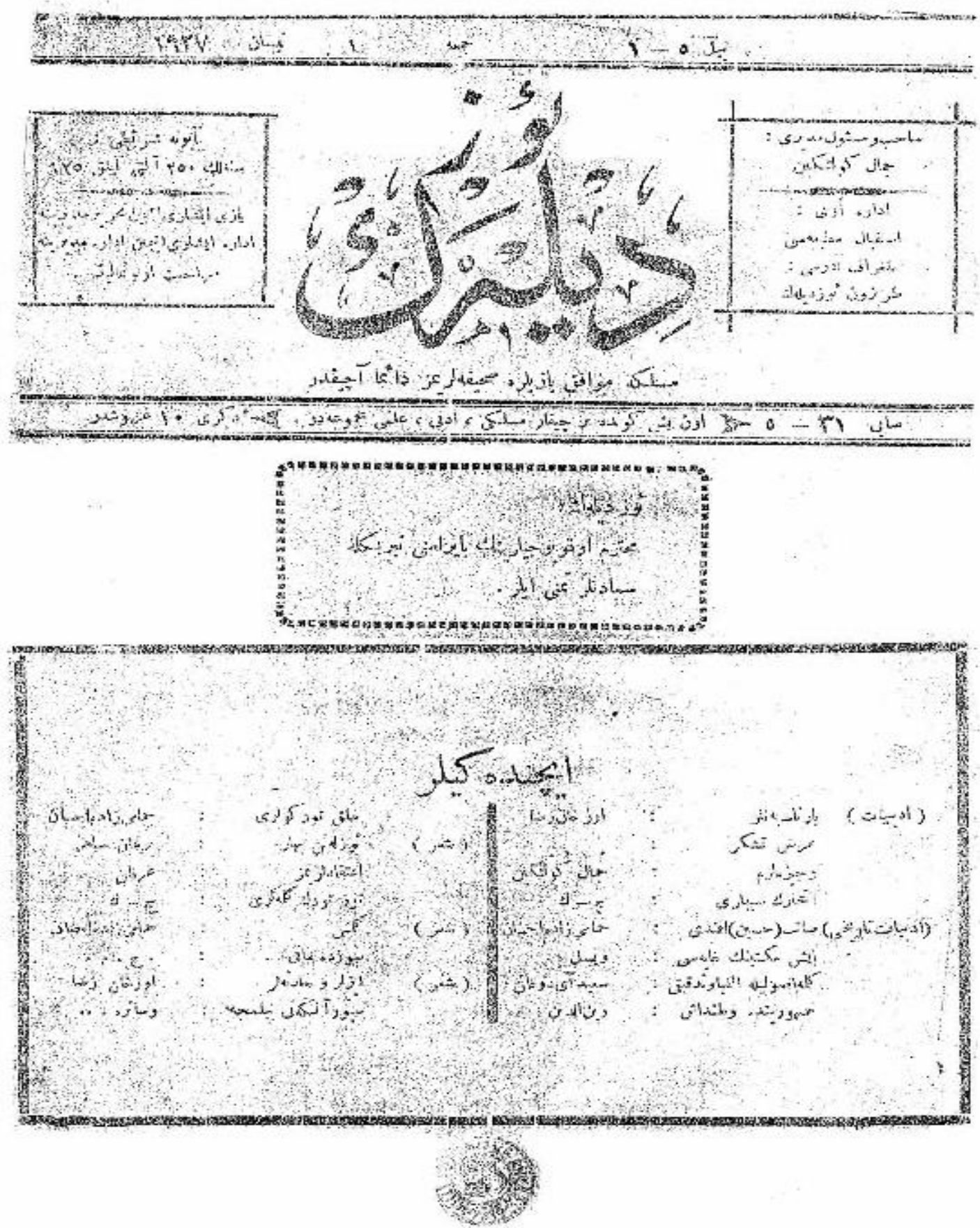

Turkish Studies, 15(1) 